\title{
How well is urban agriculture growing in the Southern United States? Trends and issues from the perspective of urban planners regulating urban agriculture
}

\author{
Russell Fricano a * \\ Minnesota State University Mankato \\ Carla Davis ${ }^{b}$ \\ Alabama A\&M University
}

\begin{abstract}
Submitted January 28, 2019 / Revised April 26 and May 19, 2019 / Accepted May 20, 2019 /
Published online January 7, 2020

Citation: Fricano, R., \& Davis, C. (2020). How well is urban agriculture growing in the Southern United States? Trends and issues from the perspective of urban planners regulating urban agriculture. Journal of Agriculture, Food Systems, and Community Development, 9(2), 31-53. https://doi.org/10.5304/jafscd.2020.092.001
\end{abstract}

Copyright (C 2020 by the Authors. Published by the Lyson Center for Civic Agriculture and Food Systems. Open access under CC-BY license.

\begin{abstract}
In this study, we evaluate urban agriculture trends in 55 cities in the Southern United States. Our research is important for three reasons. First, as the geographic scope of urban agriculture research is limited mostly to Northeast and West Coast cities, we focus on the South, the fastest-growing U.S. Census region. Second, despite rapid growth, this region has also experienced the highest rate of poverty and food insecurity. Third, we surveyed urban planners who regulate and monitor urban agriculture sites, develop urban agriculture policies

a* Corresponding author: Russell Fricano, Associate Professor, Minnesota State University Mankato, Urban \& Regional Studies Institute; 106 Morris Hall; Mankato, MN 56001 USA; +1-506-389-1540; russell.fricano@mnsu.edu

Some of the research for this paper was conducted while Fricano was Assistant Professor, Alabama A\&M University, Normal, Alabama.

b Carla Davis, Department of Community \& Regional Planning, Alabama A\&M University, Normal, Alabama.

Davis is now a planner with the City of Fairhope (Alabama) Department of Planning and Zoning.
\end{abstract}

and programs, and advise local decision-makers. The study documents Southern urban agriculture changes between 2000 and 2010. It also considers types of projects, implementation barriers, and strategies used to promote urban agriculture. A survey questionnaire was mailed to planning officials in 153 Southern cities; 55 cities responded. Among respondents, 87\% reported the existence of urban agriculture in their jurisdiction. Most Southern cities reporting urban agriculture experienced urban agriculture growth (69\%), 21\% reported decline, and 10\% did not report a change. The most common projects included neighborhood gardens, school gardens, and community supported and entrepreneurial agriculture. Irrespective of urban agriculture growth or decline, the responding cities relied on the same types of regulatory and policy approaches. Only cities reporting

\section{Funding Disclosure}

The authors are indebted to Alabama A\&M University Department of Community and Regional Planning for providing a portion of the funding for this project. 
growth in urban agriculture implemented programs to promote urban agriculture, including land acquisition, trusts, and interjurisdictional coordination. Land conversion and lack of economic sustainability were cited as main barriers to urban agriculture. The findings suggest the need to further explore the impact of external factors on the effectiveness of urban agriculture regulations, policies and programs, and solutions to urban agriculture barriers.

\section{Keywords}

Urban Agriculture, Urban Planners, Land Use, Southern United States

\section{Introduction}

Urban agriculture is an important component of a larger community food system, providing nutrition, green development, economic opportunities, and resilience to the urban environment. Most of our knowledge of urban agriculture comes from case studies of successful urban agriculture programs and surveys primarily focusing on community garden stakeholders at a site-specific level. In the process, research has identified what has made urban agriculture successful as well as what impedes its progress. Successful urban agriculture strategies consist of favorable site conditions, entrepreneurship, agricultural cultivation techniques, land, labor, capital, consumer demand, and distribution channels (Hodgson, Campbell, \& Bailkey, 2011; Tixier \& Bonn, 2006; Veenhuizen, 2006). In addition, Hodgson et al. (2011), Sharp, Jackson-Smith, and Smith (2011), and Raja, Born and Kozlowski-Russell (2008) also emphasize the importance of the regional component of food systems and community food councils, comprehensive urban agriculture and land resource studies, and the incorporation of urban agriculture in local comprehensive and regional plans. Conversely, research has also revealed various barriers to urban agriculture, including site-related (physical and biological characteristics) issues, restrictive or poorly defined regulations and policies, lack of agricultural training and experience, land tenure issues, organizational and institutional obstacles, and negative public perceptions (American Community Garden Association [ACGA], 1998; Hodgson et al., 2011; Kaufman \& Bailkey, 2000; Mukherji \& Morales, 2010).

While these studies provide important information, certain issues that affect urban agriculture growth and decline remain unexplored: First, Guitart, Pickering and Byrne (2012) noted that the geographic scope of community garden research was predominantly limited to Northeast and West Coast cities. The question, then, is how well urban agriculture has grown in the South? ${ }^{1}$ This is especially important as the South experienced the highest rate of growth in population (14\%) compared to other U.S. regions from 2000 to 2010 (U.S. Census Bureau, 2011b).

Second, the Southern region consistently experienced the highest rate of poverty among U.S. regions from 1959 to 2017 (U.S. Census Bureau, 2018). As noted by Coleman-Jensen, Rabbitt, Gregory, and Singh (2018), households with income near or below the poverty level also reported higher rates of food insecurity. Further, according to the U.S. Department of Agriculture Economic Research Service (USDA ERS), eight states, or $80 \%$ of states in this region, reported food insecurity above the national average (USDA, 2017a; 2017b); 8.3\% of Southern households reported "low food security," and 5.1\% reported "very low food security." Compared with other U.S. Census regions, these are the highest incidences of food insecurity in the U.S. (ColemanJenson et al., 2018).

Third, this study addresses perceived urban agriculture trends over a set time frame within cities. Most studies are conducted either at one point in time or in inconsistent time frames. Equally important are trends at the perspective of the city level. City jurisdiction perspectives are crucial, as that is where land use policy and regulation take place. These functions are under the purview of local government planning, which can permit, restrict, or

\footnotetext{
1 We refer to the Southern region as delineated by the U.S. Census Bureau American Community Survey Office (2018) - Census Regions and Divisions in the United State. This includes Alabama, Arkansas, Delaware, Florida, Georgia, Kentucky, Louisiana, Maryland, Mississippi, North Carolina, Oklahoma, South Carolina, Tennessee, Texas, Virginia, and West Virginia.
} 
replace urban agriculture projects. It follows that perspectives are needed from planners who work closely with the city council and planning commission to regulate urban agriculture and develop policies that promote it.

This leads to our fourth issue: The extent cities implement regulations, policies, and programs that preserve and promote urban agriculture is not adequately covered in research. The American Planning Association report by Hodgson et al. (2011) and related research by Campbell (2004) and Kaufman and Bailkey (2000) provide a detailed list of planning strategies that maintain and promote urban agriculture. We examine the extent to which these approaches are followed from the perspective of urban planners.

Fifth, we examine how well research identifies barriers to urban agriculture. For urban agriculture to be successful, barriers must be more thoroughly identified and anticipated. There is some discussion of barriers in the literature, but these works primarily focus on site characteristics, restrictive regulations, or land tenure issues.

Finally, we also consider the extent of interjurisdictional coordination. Cities that are highly urbanized look to peri-urban areas outside the local jurisdiction for potential urban agriculture sites. To accomplish this requires interjurisdictional coordination, which planners initiate.

This research addresses these issues by surveying local government planners. Planners can provide important insight into urban agriculture in several ways. They view urban agriculture from a comprehensive perspective at the city and regional levels, thereby placing them in a position to view urban agriculture and other food system issues in the context of other local considerations

(Pothukuchi \& Kaufman, 1999).

Planners administer a permitting system for the development of land that includes urban agriculture projects. The outcomes of these decisions are part of their day-to-day work, and they are also legally required to maintain records of these decisions. Planners also periodically update existing land use maps utilizing field investigation, aerial photos, and geographic information systems (GIS). They also monitor and rectify zoning violations.

Further, planners work closely with planning commissions and city councils, which have authority in land use decisions. In the process, they advise decision-makers on ways of promoting urban agriculture in local comprehensive planning policies. Planners also implement policies through zoning and other forms of land use regulation and coordinate land development with adjacent jurisdictions. Further, Campbell (2004) emphasized a role for planners as a food system partner that includes revising local land use plans and regulations to promote local food systems. Thibert (2012), Hodgson et al. (2011), and Kaufman and Bailkey (2000) share these suggestions.

Utilizing a planner's perspective with a Southern geographic scope, this study adds to the existing literature by examining perceived urban agriculture growth and decline over a 10-year period. Based on a citywide level in the Southern U.S. region, the study also explores types of projects, approaches used to regulate and promote urban agriculture, the extent of interjurisdictional coordination, and barriers to urban agriculture faced by the survey respondents. Further, we detail changes in urban agriculture through planners' observations based on their knowledge of local land development trends, changes in cultivated acres, and the number of agricultural projects.

The definition of urban agriculture used in the survey is "a formal or organized agricultural activity within a city-sponsored by government, nonprofit, or private organizations." "Organized" cultivation of land places urban agriculture within the scope of land use regulation and policy.

This research also views urban agriculture in three capacities: (a) community-oriented crops grown for neighborhood consumption and community supported agriculture; (b) entrepreneurial farming: cultivating crops or raising livestock for small business development and job training; and (c) institutional farming taking place in public parks, municipally owned land, public housing locations, and educational institutions. We based our taxonomy on projects classified by the American Planning Association (Hodgson, Campbell, \& Bailkey, 2011) and the American Community Gardening Association National Survey (ACGA, 1998). We do not include one-shot projects in our definition, as they are difficult to track, have a 
comparatively shorter life, and do not provide an understanding of the long-term allocation of vacant urban space.

While literature also places farmers markets and peri-urban agriculture within the definition of urban agriculture, we do not include these practices. Regarding distribution, farmers markets do not always sell local food products. In contrast, onsite sales at urban farm sites better fit this definition.

Peri-urban agriculture is practiced on the edge of urban areas and therefore would be outside the authority of our surveyed cities. However, we do recognize the value of peri-urban agriculture, especially when land for growing crops in cities becomes developed or redeveloped, making farmland scarce; proximity to the urban area provides replacement sites. Peri-urban agriculture also facilitates the rural-urban interface, offering farming opportunities for high-value, perishable products near cities and reducing transport costs and energy usage (Heimlich, 2001; Oberholtzer, Clancy, \& Esseks, 2010). For these reasons, peri-urban agriculture is examined by exploring whether the surveyed cities coordinate with adjacent jurisdictions.

Studies of community gardens often focus on specific sites. However, the focus on community gardens prevents the documentation of other types of urban agriculture, including specialized agricultural, ranching, dairy, livestock, or permaculture projects—collectively defined as entrepreneurial agriculture. They also disregard private/public research or university-sponsored projects. Further, site-specific studies are not comprehensive.; they ignore overall trends in urban agriculture in a specific jurisdiction.

\section{Literature Review}

Our survey of the literature on urban agriculture revealed three categories: first, programs and practices that lead to successful urban agriculture; second, research detailing barriers to implementing urban agriculture; and last, case studies and surveys of community garden organizations and stakeholders documenting gardening initiatives.

Successful urban agriculture consists of interdependent components that include site condi- tions, entrepreneurship, agricultural cultivation techniques, land, labor, capital, consumer demand, and distribution channels (Hodgson et al., 2011; Tixier \& Bonn, 2006; Veenhuizen, 2006). Other works have shown the importance of the regional component and community food councils, community food assessments, comprehensive urban agriculture and land resource studies, and the incorporation of urban agriculture in local comprehensive and regional plans (Hodgson et al., 2011; Raja, Born, \& Kozlowski-Russell, 2008; Raja \& Campbell, 2014; Sharp, Jackson-Smith, \& Smith, 2011).

School gardens also play a special role in improving nutritional education and behavior. Ratcliffe, Merrigan, Rogers, and Goldberg (2011) found that school gardening improved students' willingness to taste and consume vegetables. According to research by Parmer, SalisburyGlennon, Shannon, and Struempler (2009), school gardens were associated with knowledge of fruit and vegetables and nutritious consumption behavior. Graham, Beall, Lussier, McLaughlin and Zidenberg-Cherr (2005) also found that as a form of academic instruction, schools used gardens primarily for teaching science, environmental concepts, and nutrition.

Major collaborative programs formed by urban agriculture stakeholders coordinate efforts over a regional area with a variety of non-agricultural stakeholders, including environmental protection and greening groups, schools, city agencies, charitable foundations, and volunteer organizations (Krones \& Edelson, 2011). Community participation also provides an opportunity for public education, shaping perceptions of urban agriculture, and provides training to prospective urban farmers (Bleasedale, Crouch, \& Harlan, 2011; Covert \& Morales, 2014; Feenstra, McGrew \& Campbell, 1999; Kaufman \& Bailkey, 2000).

Other studies discuss planning methods that facilitate urban agriculture. Cities can promote urban agriculture through comprehensive planning policies to fulfill broader goals such as open space preservation and food access (Hodgson et al., 2011). Modifying standalone agriculture ordinances and zoning districts can make vacant parcels conducive to multifunctional agricultural use (Lovell, 
2010). Mukherji and Morales (2010) also suggested that planners may want to promote agriculture that is more intensive as permitted uses but limit the extent of such uses through a conditional use permit process to avoid nuisances.

The practice of urban agriculture has encountered various barriers throughout its history. These barriers fall into six main categories: site-related (physical and biological characteristics), restrictive or poorly defined regulations and policies, lack of agricultural training and experience, land tenure issues, organizational/institutional obstacles, and negative public perceptions (ACGA, 1998; Hodgson et al., 2011; Kaufman \& Bailkey, 2000; Mukherji \& Morales, 2010).

Regulatory and policy barriers include restrictions imposed on urban agriculture by zoning and comprehensive planning (Castillo, Winkle, Krauss, Turkewitz, Silva, \& Heinemann, 2013; Lovell, 2010; Masson-Minock \& Stockman, 2010; Mukherji, 2009; Mukherij \& Morales, 2010). Comprehensive planning policies can promote sustainable development, including redevelopment, urban forestry, and other forms of land use that compete with urban agriculture practices (Lovell, 2010).

Agricultural and entrepreneurial skills are essential for a successful business. Urban farming operations have the added burdens of the seasonal nature of food production, shortages of qualified, experienced staff, and missing educational programs and training for both the farmer and staff (ACGA, 1998; Bleasedale, Crouch, \& Harlan, 2011; Kaufman \& Bailkey, 2000).

Land tenure is widely discussed in the literature. Agricultural enterprises are fixed to the land. If land is sold or converted to another use, relocating an urban farming project to another location is difficult, if not impossible. Landowners commonly lease vacant lots to urban agricultural interests for the short term, but convert to other, more profitable uses as opportunities arise. The urban farmer has no assurance of the continued use of the site for cultivation from year to year (Castillo et al., 2013; Hodgson et al., 2011; Kaufman \& Bailkey, 2000; Schmelzkopf, 1995; Schukoske, 2000). In cases where replacement sites are available, the cost of moving from one site to another can be prohibitive (Castillo et al., 2013).

Organizational and institutional obstacles also complicate or prevent the establishment of urban agriculture projects. These obstacles can include competing priorities with other projects (Lovell, 2010; Schmelzkopf, 1995), jurisdictional issues over which governmental organization regulates community gardens (e.g., parks or planning), and independent urban agriculture programs that conduct operations without strong institutional support and coordination (Feenstra et al., 1999; Linn, 1999; Mukherji, 2009; Smith \& Kurtz, 2003).

Perceptions of negative agricultural impacts and questions over the legitimacy of agricultural use within city boundaries as a nonformalized process can sometimes cause resistance. Following World War II, cities relegated food processing and related uses to industrial zones, with food markets shifting to retail supermarket outlets (Donofrio, 2014). These perceptions have persisted into contemporary times over potential nuisances and lawless activities. When urban agriculture advocates propose or implement projects, residents often develop a "not in my backyard" (NIMBY) attitude toward urban agriculture, which can obstruct project approval or the adoption of urban agriculture ordinances (Covert \& Morales, 2014).

Studies of urban agriculture practices and programs consist mainly of surveys and case studies focusing on successful programs. We note two surveys conducted by the American Community Garden Association (ACGA, 1998; Lawson \& Drake, 2012) and another by the National Center for Appropriate Technology (NCAT) (Oberholtzer, Dimitri \& Pressman, 2016). Three prominent case studies include those conducted by the Lincoln Institute (Kaufman \& Bailkey, 2000), the American Planning Association Report (Hodgson, Campbell \& Bailkey, 2011) and Thibert (2012).

Perhaps the most comprehensive work on current urban agriculture practices from a planning perspective is the American Planning Association's Planning Advisory Service Report, Urban Agriculture: Growing Healthy, Sustainable Cities (Hodgson et al., 2011). The study closely analyzed urban agriculture policies and programs in 11 North American cities. Based on interviews with local government officials, planners, and urban agriculture practi- 
tioners, the study compared differences in urban agriculture approaches between jurisdictions and provided guidelines to urban planners interested in promoting agriculture. The authors concluded that engaged political leadership and support of urban agriculture stakeholders provided a foundation for successful urban agriculture policy development and implementation. They also stressed that planners could utilize traditional planning tools and approaches to facilitate the process.

Thibert (2012) also followed a case study approach, interviewing 14 urban agriculture stakeholders in Detroit, Toronto, and Montreal. He emphasized that the slow acceptance of urban agriculture was a perception of agricultural use traditionally segregated from urban land uses, as it was considered incompatible. The concept of "highest and best use" of land remains fundamental. Further, planners do not normally consider food systems as part of their professional domain, and its transdisciplinary nature can cause it to be disregarded. Residents in disadvantaged communities have difficulty accepting urban agriculture as a form of food security or economic opportunity. Thibert further highlights that given differences in urban agriculture practices as well as cultural, legal, and technical challenges, municipalities should utilize their traditional role in land use planning to enable urban agriculture.

Three surveys conducted by the American Community Gardening Association (ACGA) in 1992, 1998, and 2012 illustrate long-term trends in urban agriculture. The ACGA initially compiled information on community garden organizations in 1992. The subsequent survey of 1998 gave the ACGA the opportunity to compare trends over the past five years among those that originally took the 1992 survey. In addition, the 1998 survey compiled the responses of organizations conducting urban agriculture practices in 38 U.S. cities. This survey is of great value in recognizing contemporary American urban agriculture and classifying its various practices.

In most cases, respondents cited the land tenure as an issue. The survey also provided the status of community garden loss and gain. Gains exceeded losses: The survey reported the loss of community gardens at $9 \%$, with the creation of new gardens at 38\% (ACGA, 1998). Major reasons cited for garden loss included lack of interest by gardeners and the loss of public and private owners (land tenure). Only a relative minority of respondents $(39 \%)$ reported open space initiatives to preserve urban farmland (ACGA, 1998).

The 2012 ACGA study, conducted in conjunction with Rutgers University, surveyed 420 representatives of community garden associations. The survey examined diversity in gardening and changes in garden types. While some of the same types of issues were explored in the 1998 and 2012 surveys, the 2012 survey departed from the previous measurement of number of sites and disaggregated community garden sites and examined those established by small, medium, large, and very large organizations. The report noted increases in the number of gardens in each category as well as in the size of the sites.

The 2012 study documented garden growth or loss over a four-year period from 2007 to 2011. Measurement relied on waiting lists and respondents' knowledge of other gardens in the area. Most respondents $(89 \%)$ reported an increase, followed by no change $(10 \%)$ and decline (1\%) (Lawson \& Drake, 2012). Respondents attributed the garden loss to lack of gardener interest, loss of land to private organizations, loss of funding, and loss of land to public agencies. Respondents also reported that the main challenges for community gardens were funding, recruitment of community members, access, and gardening materials. The survey also detailed information on collaboration and partnerships at various levels and through land trusts (Lawson \& Drake, 2012).

While we recognize the value of community garden studies, we extend the scope to include other forms of urban agriculture that include entrepreneurial and public or private research projects. This can be done through the perspective of planners who monitor and regulate land use. We also view urban agriculture over a more consistent time frame.

NCAT published another survey on urban farming practices in 2016 that focused on the risks and economics of urban agriculture (Oberholtzer, Dimitri \& Pressman, 2016). While this study did not measure growth or decline in urban farming, it 
provided useful statistics on urban farming operations. The survey interviewed 315 urban farmers across the U.S. and examined basic statistics of urban farming, which include number of acres, years in production, number of primary farmers and managers, number of farmworkers, and type of operation (nonprofit, sole proprietorship, etc.). The study also considered ownership statistics and lease terms, production practices in terms of crops and livestock, sales, and marketing practices. The survey interviewed urban agriculture stakeholders in 15 cities where urban agriculture was considered to be increasing (Oberholtzer et al., 2016).

Land tenure emerged as a significant factor, as most responding farmers either leased their land or borrowed their land in an informal arrangement. The study further shed light on entrepreneurial agriculture. Most of the sites were operated under a form of business entity and sold some of their products. Most farmers owned and operated more than one site.

Along with entrepreneurial activity, economic viability (the ability of urban farmers to live off the revenue of their operation) was another major concern: $60 \%$ of the farms were sustained with offfarm income, and approximately $33 \%$ of the primary farmers derived their income from the farm; most urban farmers reported revenue of less than US $\$ 10,000$; the small size of sites precluded largevolume operations. Further areas of concern reported by stakeholders included policy differences, profitability, financing, and farm labor. Respondents also expressed needs for business education and technical assistance (Oberholtzer et al., 2016).

In summary, the existing urban agricultural literature primarily explores trends and other issues through case studies and survey instruments. Neighborhood gardens are the predominant form of urban agriculture, followed by entrepreneurial farming, school gardens, and other forms of farming accessory to an institutional use. Most urban agriculture research focuses on community gardeners at site-specific levels. In this manner, the literature takes a grassroots emphasis aligned with community garden stakeholders. From these studies we receive a general impression that urban agriculture is growing in terms of number of sites devoted to neighborhood gardens; the reasons for growth include organized initiatives to preserve urban farmland. Decline or loss of agricultural land was attributed to lack of gardener interest, loss of land, funding issues, and economic sustainability.

Despite these findings, various issues remain.

The narrow focus on community gardens prevents documenting larger economic and land use issues associated with urban agriculture. Apart from the survey by Oberholtzer et al. (2016), these studies did not document larger specialized agricultural, ranching, dairy, livestock or permaculture projects, collectively defined as entrepreneurial agriculture, nor private or public research or universitysponsored projects. Regional differences in the U.S. should also be considered. The geographic scope of most community garden research was limited mostly to Northeast and West Coast cities. Further, these studies lack consistent long-term documentation of urban agriculture. Case studies are normally conducted at one point in time, and the ACGA surveys did not consider consistent time spans or precise ways of measuring trends.

The site-specific emphasis by previously mentioned community gardens studies complicates assessing urban agriculture trends at the citywide level. As indicated in Oberholtzer et al. (2016), urban farmers can own more than one site, which can straddle jurisdictions. This issue also emerges with peri-urban farming.

The literature also provides working examples of prescriptive approaches intended to facilitate urban agriculture. These include land resource studies, land acquisition, open space initiatives, and policies that promote urban agriculture in local comprehensive and regional plans (AGCA, 1998; Kaufman \& Bailkey, 2000; Lawson \& Drake, 2012). While prescriptive approaches serve as useful models, the extent to which these approaches are used and are effective warrants further consideration.

Finally, previous surveys did not utilize the observations of planners intimately involved in the local land development process. Information provided by local government planners can build on these studies. This is crucial given that urban agriculture projects are subject to review and approval by the local planning department, planning com- 
mission, and city council.

Planners implement land use regulations and policies that affect urban agriculture. Community gardens and other forms of urban agriculture are subject to zoning and supporting policies in the comprehensive plan. Further, the planning department and tax assessor are required to keep records of land-use decisions, and planners must update existing land-use maps based on field checks. In their enforcement capacity, they also monitor local development for zoning violations. These responsibilities put planners in a favorable position to identify various obstacles. This method of analysis provides an opportunity to compare differences in policies and regulation of urban agriculture between jurisdictions.

\section{Research Design}

\section{Research Questions}

This research explores answers to the following questions:

- According to city planners, how well has urban agriculture grown in Southern U.S. cities? Has it grown, declined, or remained the same?

- What do trends in urban agriculture reflect over a 10 -year period?

- To what extent do cities implement prescriptive approaches intended to preserve and enhance urban agriculture?

- What are the perceived barriers to urban agriculture?

- How extensive is interjurisdictional coordination?

The survey questionnaire has some similarities to and differences from the 1998 and 2012 ACGA surveys. Similarities include types of projects featured on a checklist: neighborhood gardens, public housing gardens, job training, and economic development, community supported agriculture (CSA), senior center housing gardens, and mental health center gardening projects. We also included questions about land ownership status, barriers to urban agriculture, and the presence of land preservation and acquisition strategies. The barriers we surveyed followed those of the 1998 ACGA survey, with the addition of gentrification.

We designed the survey to provide a checklist of popular types of urban agriculture projects and regulatory and policy tools, but we also provided spaces for open-ended responses beyond the checklist. This included other forms of urban agriculture policies and programs, additional reasons why urban agriculture has declined, and other strategies for extending local government policy in promoting urban agriculture. Checklist responses were tallied by the number of responses. Openended questions were compiled and summarized.

Conversely, our survey differed from the ACGA studies in several ways. We investigated the presence of urban agriculture approaches beyond the community garden level and extended the study to include entrepreneurial agriculture and university and research projects.

As the survey was directed at directors of planning or community development directors, it was customized so that respondents could report about urban agriculture trends as well as policies, regulations, and programs from a comprehensive perspective in their jurisdiction. We, therefore, asked planners to report on urban agriculture growth and decline in their jurisdictional boundaries. Implementation of land-use policy and regulation occurs at the citywide jurisdictional level. Using this method of documenting local changes in urban agriculture provides a more precise way to report the status of urban agriculture in a jurisdiction. Considering farming plots irrespective of local jurisdiction location can confuse local regulatory and policy issues.

Responses for growth and decline were reported in a general manner and (if known) more precisely by total acreage and number of projects. This accurately documents growth, decline, or no change in a consistent manner.

The researchers also examined the net change in urban agriculture acreage and projects over a 10 year period, observing the magnitude of change over a longer time interval compared with other works. Change is much easier to detect over a longer time frame.

Further, by focusing on the city jurisdiction level, we sought evidence of interjurisdictional 
coordination. Coordination with adjacent jurisdictions is especially critical in cities facing severe land constraints for additional or replacement sites through peri-urban agriculture. We, therefore, provided respondents the opportunity to indicate whether their city had expanded opportunities for its urban agriculture stakeholders by coordinating with adjacent jurisdictions.

Surveying planners also provided insight into the regulatory and policy tools used in land use and their subsequent impact on urban agriculture. The survey was designed to provide a checklist of regulatory and policy tools planning officials use in their day-to-day work.

\section{Survey Sampling Methodology}

Survey data were gathered through a questionnaire mailed to planning or community development directors, based on the official's title and responsibilities. These planning officials were purposely selected due to their familiarity with land development trends and land use policy and regulation. Officials' contact information was obtained online through the cities' website and telephone inquiries.

We delineated the Southern region study area using the map of census regions published by the U.S. Census Bureau American Community Survey Office (2018). This region includes the 16 states of Alabama (AL), Arkansas (AR), Delaware (DE), Florida (FL), Georgia (GA), Kentucky (KY), Louisiana (LA), Maryland (MD), Mississippi (MS), North Carolina (NC), Oklahoma (OK), South Carolina (SC), Tennessee (TN), Texas (TX), Virginia (VA), and West Virginia (WV). Cities located in the top 300 Metropolitan Statistical Areas (MSAs) of the Southern region formed the sample group, based on the most recent U.S. Census Bureau data at the time of the survey (U.S. Census Bureau, 2011a). The sample furnished 153 subject cities in this region. Based on online research of planning departments in all Southern metropolitan and micropolitan areas, there are currently 451 planning departments in the Southern U.S.

The survey design consisted of open-ended questions, checklists, dichotomous questions requiring a "yes" or "no" response, and questions featuring Likert-scale rating. The survey instrument is provided in Appendix 1.
Respondents were asked to report trends in two ways: generically (whether urban agriculture had grown or declined), and quantified estimates of net growth or decline of urban agricultural land in acres and number of projects over the past 10 years. We also included a checklist for the types of urban agriculture projects.

Additionally, we provided a checklist of policy tools commonly noted in previous case studies. These included comprehensive plans, neighborhood plans, land use policy maps, and open space plans (Hodgson et al., 2011). Open-ended questions documented items of importance outside the checklist. In this manner, the survey gave respondents the opportunity to provide a complete listing of urban agriculture policies and programs, additional barriers to urban agriculture, and strategies for overcoming obstacles.

Our questionnaire further included a checklist of three major methods of land regulation reported in the literature: zoning, parks and recreation ordinances, and standalone urban agricultural ordinances. As in the case of policy tools, the checklist accommodated an open-ended response for other forms of regulation. Using a similar type of checklist, we further inquired about the existence of any city programs that promote urban agriculture. These include preservation of urban agriculture sites, acquisition of land for urban farming sites, and interjurisdictional coordination.

We also asked planners to document the obstacles affecting the establishment of urban agriculture using a checklist of the most commonly reported barriers in research (ACGA, 1998; Castillo et al., 2013; Kaufman \& Bailkey, 2000; Lawson \& Drake, 2012; Schmelzkopf, 1995; Schukoske, 2000); it also provided for an open-ended "Other" response.

Surveys were mailed out during the 2011/2012 academic year. The primary method of survey distribution was by mail. In certain cases, local planners provided responses by e-mail, facsimile, or a direct telephone conversation. Mailing included a reminder postcard sent to subject cities a week prior to the deadline to ensure greater response. The survey set a completion deadline within 10 days of its receipt. We granted extensions to respondents who needed additional time. The 
direct phone conversation paralleled the survey questions.

A final attempt at data collection for cities that did not respond to the first method consisted of a second mailing, three months after the first survey distribution. In certain cases, local planners provided responses by e-mail, fax, or, in one case, a telephone interview that paralleled the survey questions.

\section{Survey Analysis}

Survey responses provided the types of policy and regulatory tools and programs implemented by cities experiencing urban agriculture growth or decline. We entered responses in spreadsheet format and analyzed the data using response frequencies, measures of central tendency, proportions, rank ordering, and percentiles. The analysis documented how urban agriculture changed between 2000 and 2010 in terms of site acreage and projects, based on the perspective of planning officials.

\section{Findings}

The survey response rate was $36 \%$, with 55 out of 153 city planning officials participating in the survey; 54 cities returned the questionnaire, and one respondent answered questions in a telephone interview. Every state in the Southern region was represented. Cities and states that responded are mapped in Figure 1.

Population estimates of the responding cities were based on 2010 U.S. Census data, the most current estimates at the time of the survey. Population sizes of responding cities ranged from 1,327,407 (San Antonio, TX) to 16,413 (Marco Island, FL). The mean population size was 176,789, with a median of 76,068. Responding cities are listed in Appendix 2.
Figure 2. Reported Urban Agriculture Growth and Decline

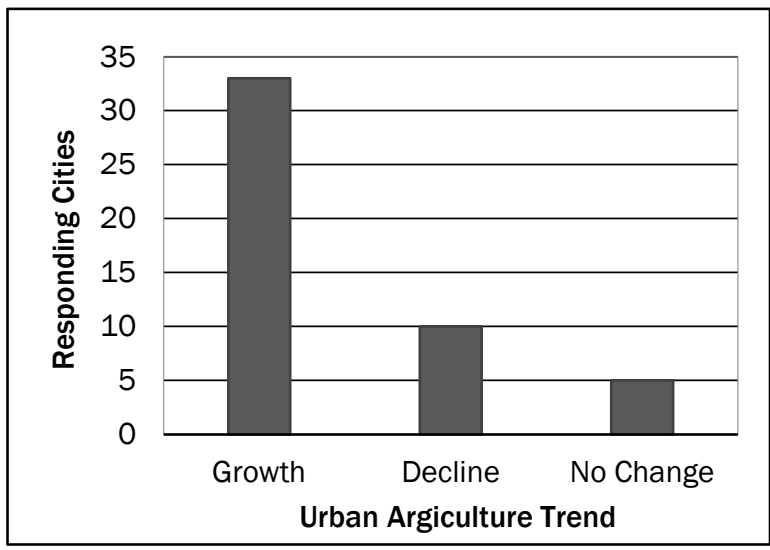

\section{Is Southern Urban Agriculture Growing?}

Figure 2 summarizes the survey responses in terms of urban agriculture growth, decline, and stability in the Southern region.

Among the 55 respondents, 48 (87\%) reported the presence of urban agriculture, and seven cities $(13 \%)$ reported no urban agriculture. Of the 48 cities reporting urban agriculture in their jurisdiction, 33 cities $(69 \%)$ noted that urban agriculture had grown (expressed generically) in their jurisdiction over the past 10 years; 10 cities with urban agriculture $(21 \%)$ indicated it had declined; five 
Table 1. Median Change in Southern Urban Agriculture over 10 Years: Acreage and Projects

\begin{tabular}{|c|c|c|c|}
\hline Cities Reporting Growth Estimates $(n=10)$ & & Cities Reporting Decline Estimates $(n=1)$ & \\
\hline Median Increase in Acres & 7 & Median Acreage Loss & $\mathrm{n} / \mathrm{a}$ \\
\hline Range in Acreage Gain & 1 to $71^{a}$ & Range in Acreage Loss & $\mathrm{n} / \mathrm{a}$ \\
\hline Total Increase in Acres & 203 & Total Acreage Loss & -100 \\
\hline Median No. of Projects & 3 & Median No. of lost Projects & $\mathrm{n} / \mathrm{a}$ \\
\hline Range in Projects & 1 to 43 & Range in Projects & $\mathrm{n} / \mathrm{a}$ \\
\hline Total No. of Projects & 163 & Total No. of Projects & $\mathrm{n} / \mathrm{a}$ \\
\hline
\end{tabular}

a Estimate reflects the removal of outlier.

cities (10\%) reported no change. The AGCA surveys also noted growth in community gardens, although the methodology differed in focusing exclusively on community gardens as opposed to other forms of urban agriculture, such as entrepreneurial and community supported agriculture (ACGA, 1998; Lawson \& Drake, 2012).

\section{Change in Urban Agriculture}

The following tables provide summaries of quantified urban agriculture growth and decline by acreage and projects, type of projects, urban agriculture policy and regulatory mechanisms, program approaches, and reasons for urban agriculture decline. It is important to note that the number of responses differs in each table, reflecting no response to certain questions in the survey.

Changes in urban agriculture acreage and number of projects over a 10 -year period served as a measure of the extent to which urban agriculture had grown or declined. Table 1 provides estimates in both acreage and number of projects. We relied on the median as a measure of central tendency to avoid skewing. The increase in acreage ranged from one to 71 acres, ${ }^{2}$ with a median of seven acres; one-acre plots were the most common.

In examining changes, 11 out of 55 respondents $(20 \%)$ reported quantified change. Responses measuring change led to two interesting observations: In cities reporting growth, the total increase in acreage across all the cities was 203 , with a median number of acres at seven; the number of projects was 163, with a median of three. According to the median, this reflects a modest growth of seven

21 acre $=0.4$ hectare acres and three projects. In contrast, total acreage loss reported by a city experiencing decline was a loss of 100 acres. However, only one respondent in this category provided an estimate of decline, and this is not sufficient to infer a trend (see Table 1).

\section{Project Type}

Respondents estimated the number of urban agriculture projects in their city by 'project type' (see Table 2). Some cities reported more than one type

Table 2. Urban Agriculture Project Types

\begin{tabular}{lcc}
\hline Project Type (n=128) & $\begin{array}{c}\text { Number of } \\
\text { Responses }\end{array}$ & Percent \\
\hline $\begin{array}{l}\text { Community (Neighborhood) } \\
\text { Garden }\end{array}$ & 34 & $27 \%$ \\
\hline School Gardens & 18 & $14 \%$ \\
\hline Community Supported Agriculture & 13 & $10 \%$ \\
\hline Commercial Farming Sites & 11 & $9 \%$ \\
\hline Senior Center/Senior Citizen & 10 & $8 \%$ \\
\hline Housing Gardens & & \\
\hline Public Housing Gardens & 9 & $7 \%$ \\
\hline University Projects & 9 & $7 \%$ \\
\hline Research Projects & 8 & $6 \%$ \\
\hline Job Training & 5 & $4 \%$ \\
\hline Youth Enterprises & 4 & $3 \%$ \\
\hline Church Gardens & 2 & $2 \%$ \\
\hline Mental Health Centers (Shelters, & 1 & $0.1 \%$ \\
Group Homes) & 1 & \\
\hline Industrial Green Belt & 1 & $0.1 \%$ \\
\hline Airport Protection Zones & 1 & $0.1 \%$ \\
\hline Land Zoned for Agricultural Forest & 1 & $0.1 \%$ \\
\hline Cattle Ranches & & \\
\hline
\end{tabular}


of urban agriculture project, which resulted in a larger sample size of 128. As shown in Table 3, the responding cities reported community (neighborhood) gardens as the most numerous type of urban agriculture project, followed by school gardens and community supported agriculture projects. Commercial farming sites and senior center or senior citizen housing gardens followed these categories. These findings are similar to the ACGA surveys, with neighborhood gardens as the most commonly reported form, while the NCAT survey indicated a prominence of commercially operated sites (ACGA, 1998; Lawson \& Drake, 2012; Oberholtzer et al., 2016). The remaining distribution suggests several categories of project types, though it should be noted that job training, which is a crucial part of urban agriculture success, accounted for only $4 \%$ of responses.

\section{Urban Agriculture Policy}

The next part of the analysis examined whether urban agriculture appears in local plan policies or is formally designated as a land use in a local plan or on a land use map. If local government clearly defines policies for urban agriculture and delineates urban farming on a land-use policy map and other documents, these offer a form of protection. This also provides more legitimacy and prominence to urban agriculture practices beyond an accessory use. We found these policy approaches in cities experiencing urban agriculture growth and decline. Tables 3 and 4 display the responses of most commonly used policy methods and break them down by cities reporting growth or decline

Table 3. Urban Agriculture Policy: Cities Reporting Growth (n=11) a

\begin{tabular}{lcc}
\hline Policy Approach & $\begin{array}{c}\text { Cities Reporting } \\
\text { Growth }\end{array}$ & Percent \\
\hline Land Use Policy Map & 6 & $30 \%$ \\
\hline Comprehensive Plan & 5 & $25 \%$ \\
\hline Open Space Plan & 5 & $25 \%$ \\
\hline Neighborhood Plan & 4 & $20 \%$ \\
\hline Total & 20 & \\
\hline
\end{tabular}

a $n$ reflects those cities that responded to this question and does not consist of all the cities reporting growth. Some cities reported more than one policy approach. in urban agriculture.

Not all of the 34 cities that reported urban agriculture growth responded to this question. Only 11 complete responses were received; the remaining left the questions blank. In general, communities reporting growth designated urban agriculture mostly in land-use policy maps and comprehensive and open-space plans. Cities reporting decline relied mostly on land-use policy mapping and comprehensive plans. In comparison, the American Planning Association survey found that its surveyed cities (21) relied on comprehensive plans, followed by sustainability plans (14). Among the cities responding to the APA survey, two Southern cities reported comprehensive planning, and one city included urban agriculture in a sustainability plan (Hodgson et al., 2011).

\section{Regulating Urban Agriculture}

Tables 5 and 6 depict regulatory mechanisms that responding cities employed to regulate urban agriculture. At this point, we note that not all cities responded to this question; these findings reflect those that reported these mechanisms. Most cities, regardless of growth or decline, primarily used their zoning and animal control ordinances; those reporting growth also relied more on the Parks and Recreation ordinance. Most respondents included urban agriculture in existing ordinances rather than developing a specific "standalone" form of regulation; only one city reported an ordinance specifically devoted to urban agriculture. Zoning and animal Control Regulations were also more prevalent in cities surveyed by the American Planning

Table 4. Urban Agriculture Policy: Cities Reporting Decline $(n=4)$ a *

\begin{tabular}{lcc}
\hline Policy Approach & $\begin{array}{c}\text { Cities Reporting } \\
\text { Decline }\end{array}$ & Percent \\
\hline Land Use Policy Map & 4 & $57 \%$ \\
\hline Comprehensive Plan & 3 & $43 \%$ \\
\hline Neighborhood Plan & 0 & $0 \%$ \\
\hline Open Space Plan & 0 & $0 \%$ \\
\hline Total & 7 & \\
\hline
\end{tabular}

a $n$ reflects those cities that responded to this question and does not consist of all the cities reporting a decline. Some cities reported more than one policy approach. 
Association; 46 cities reported zoning ordinances and 13 used animal control ordinances. Of these responding cities, four cities were located in the southern U.S.

\section{Urban Agriculture Program Approaches}

Table 7 lists urban agriculture program approaches by three main types: land acquisition, preservation, and interjurisdictional coordination. Only cities reporting growth implemented these programs. Looking at the findings in the aggregate, only $9 \%$ of cities reported land preservation programs; $15 \%$ acquired land for additional sites, and 12\% coordinated with adjacent jurisdictions.

\section{Major Reasons for Urban Agriculture Decline} Figure 3 depicts the responses of cities that experi-

Table 5. Regulation of Urban Agriculture: Cities Reporting Growth $(n=20)^{a}$

\begin{tabular}{lcc}
\hline Regulatory Approach & $\begin{array}{c}\text { Cities } \\
\text { Reporting } \\
\text { Growth }\end{array}$ & Percent \\
\hline Zoning Ordinance & 18 & $75 \%$ \\
\hline Parks \& Recreation Ordinance & 3 & $13 \%$ \\
\hline Urban Agriculture Ordinance & 1 & $4 \%$ \\
\hline Animal Control Ordinance & 1 & $4 \%$ \\
\hline Community Garden & & \\
\hline Agreement Form & 1 & $4 \%$ \\
\hline Total & 24 & \\
\hline
\end{tabular}

a $n$ reflects those cities that responded to this question and does not consist of all the cities reporting growth. Some cities reported more than one regulatory approach.

Table 6. Regulation of Urban Agriculture: Cities Reporting Decline $(n=9)^{a}$

\begin{tabular}{lcc}
\hline Regulatory Approach & $\begin{array}{c}\text { Cities } \\
\text { Reporting } \\
\text { Decline }\end{array}$ & Percent \\
\hline Zoning Ordinance & 9 & $90 \%$ \\
\hline Animal Control & & \\
\hline Ordinance & 1 & $10 \%$ \\
\hline Total & 10 & \\
\hline
\end{tabular}

a $n$ reflects those cities that responded to this question and does not consist of all the cities reporting decline. Some cities reported more than one regulatory approach. enced a decline in urban agriculture programs. Respondents were given the opportunity to check all those reasons that applied, with some cities reporting more than one. Respondents indicated that the conversion of private land to residential and nonresidential use was the most prevalent reason. This was followed by the failure of the site to maintain itself economically and conversion of land for community development projects. These responses were similar to the ACGA and NCAT studies.

\section{Discussion}

This analysis examined trends in urban agriculture in the Southern U.S. over a 10 -year period as reported by planning officials. We first looked at trends in terms of urban agriculture growth and decline and then explored the reasons behind the changes. In the process, we compared our findings with other studies.

First, is urban agriculture growing? Among municipalities reporting urban agriculture, 69\% noted that urban agriculture had grown over the 10 years specified in the survey, $21 \%$ of respondents indicated it had declined, and 10\% reported no change. Expressed generically, this finding also corresponds to ACGA surveys, although these surveys

Table 7. Programs for Preservation and Enhancement of Urban Agriculture

\begin{tabular}{lcc}
\hline Program Approach & $\begin{array}{c}\text { Cities } \\
\text { Reporting } \\
\text { Growth }\end{array}$ & Percent \\
\hline Land Preservation $(n=33)$ & 3 & $9 \%$ \\
\hline Yes & 30 & $91 \%$ \\
\hline No & 33 & $100 \%$ \\
\hline Total & & \\
\hline Land Acquisition $(n=33)$ & 5 & $15 \%$ \\
\hline Yes & 28 & $85 \%$ \\
\hline No & 33 & $100 \%$ \\
\hline Total & & \\
\hline Interjurisdictional Coordination & & \\
$(n=33)$ & 4 & $12 \%$ \\
\hline Yes & 29 & $88 \%$ \\
\hline No & 33 & $100 \%$ \\
\hline Total & &
\end{tabular}


Figure 3. Reported Reasons for Urban Agriculture Decline ( $n=10)$

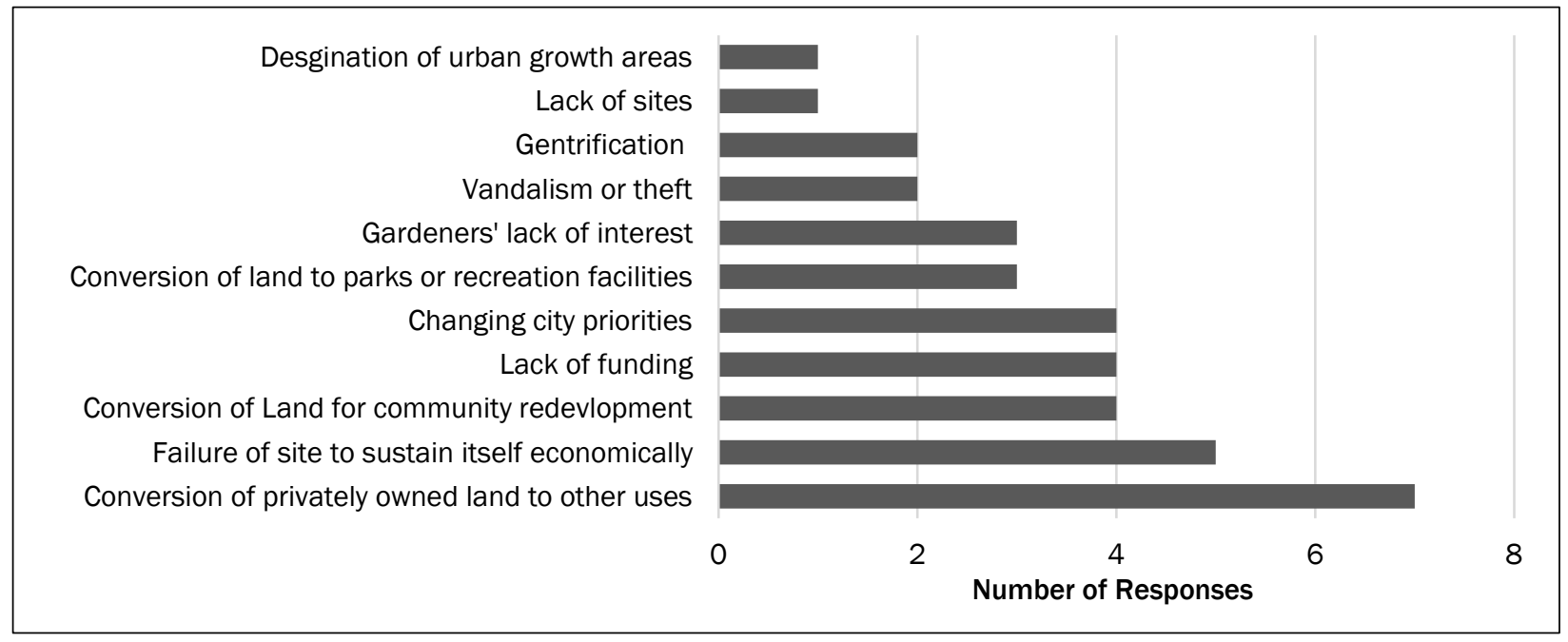

used some different approaches by surveying community garden stakeholders (ACGA, 1998; Lawson \& Drake, 2012).

While the Southern U.S. may not be characteristic of regions that normally receive the most attention in the literature, the South is the fastestgrowing region in the nation, and it is important to explore urban agriculture trends in this dynamic environment. Expanding the geographic scope to include previously understudied regions and cities provides an opportunity to review trends where urban agriculture has since developed.

This study also found that while a majority of our sample cities reported growth in urban agriculture, the median rate of growth in acreage and number of projects is modest in comparison to the loss of agricultural land and projects in cities that reported a decline. We add a caveat that this sample size is not sufficient to draw an inference. Regardless, the findings that growth was more modest and decline more pronounced call for further analysis of those cities reporting decline.

While most literature focuses on the growth or decline of urban agriculture, it is also important to devote attention to communities that report no change, maintaining the status quo. This implies preservation of agricultural land use in the face of likely loss of land and/or pressure to reduce activities. The "no change" data represent an important point of analysis for determining the success or failure of an urban agriculture policy. We suggest that future research combine the no change data and growth data calculations.

Looking more closely at types of projects, these findings related to both the ACGA and NCAT surveys. The ACGA surveys focused on community gardens, with neighborhood gardens as the most prominent type. Our study also found this was the most common practice among Southern cities. In contrast, we also surveyed cities for commercial agriculture and found it represented $9 \%$ of responses, ranked within the top three. The NCAT study noted that over $50 \%$ of respondents practiced urban agriculture under some form of commercial operation. We feel that subsequent studies should go beyond community gardens to consider all forms of local urban agriculture.

So why do some cities experience growth and others decline? We examined policy and regulatory methods to see if this could provide a clue; however, it did not. Regarding policies and regulations, the literature presented prescriptive approaches for facilitating urban agriculture growth. These included comprehensive planning policies to fulfill broader goals, such as open space preservation and food access (Hodgson et al., 2011). However, we found that both those cities reporting urban agriculture growth and those reporting decline used policy approaches similar to those noted in the literature. These included neighborhood, comprehensive, and open space plans. For the surveyed cities, the implementation of policy does not 
necessarily guarantee growth in urban agriculture.

The same holds true for land-use regulation. Lovell (2010) suggested the use of standalone agriculture ordinances and zoning districts to promote multifunctional agricultural use. However, only 3\% of Southern cities reporting urban agriculture growth used this approach. Traditional forms of regulation, including zoning, animal control, and Parks and Recreation ordinances were used instead.

Open space initiatives have been noted as a means to preserve urban farmland, yet less than half the respondents (39\%) to the 1998 ACGA survey reported such initiatives. The 2012 ACGA survey noted that access to material and land were essential for the ongoing success of community gardening(Lawson \& Drake, 2012).

Only cities that experienced urban agriculture growth implemented programs to preserve and enhance agriculture. Looking at our survey findings in the aggregate, a small proportion of cities used land preservation and acquisition programs; only $9 \%$ of surveyed cities reported land preservation programs and 15\% acquired land for additional sites. The reason a smaller proportion of responding cities reported these programs could relate to another obstacle reported by the ACGA surveys: funding. According to Lawson and Drake (2012), $15 \%$ of respondents reported loss of funding; further, $61 \%$ identified it as the most challenging issue. Additionally, only $12 \%$ of the responding Southern cities coordinated with adjacent jurisdictions. Most urban agriculture is conducted on temporary leaseholdings of land. Under conditions of land conversion to other uses within cities (i.e., redevelopment), urban famers seek other sites for relocation that can include peri-urban land. This is crucial in maintaining a viable program in exurban areas.

The primary barriers to urban agriculture identified in this study include conversion of land out of production and failure to maintain the site economically. Land conversion is widely discussed in the literature. The ACGA study of 1998 noted that site permanency was an issue with nearly every respondent. At that time, only $5 \%$ of the survey respondents reported that their land was farmerowned. Land conversion also relates to urban expansion, which includes housing projects and nonresidentail development.

Inability to maintain the site economically (inability to live off the proceeds of the site) was the second-highest reported obstacle in our findings. This is consistent with the NCAT findings: Approximately one-third of the primary farmers derived their income from the farm; most farmers reported income of less than US $\$ 10,000$. The small size of sites precluded large-volume operations.

Further areas of concern reported by stakeholders included policy differences, profitability, financing, and farm labor. Respondents also expressed needs for business education and technical assistance (Oberholtzer et al., 2016).

These findings generate unanswered questions concerning declines in urban agriculture. First, irrespective of urban agriculture growth or decline, planning officials reported that their cities implemented the same policy and regulatory approaches. These findings imply that it is not so much the presence of a policy or regulatory mechanism that affects the outcome, but how these approaches are implemented. Further exploration of the effectiveness of these approaches is needed, not only focusing on successful programs but also on those that experience decline and face obstacles.

Second, more needs to be done to identify and add land to the urban farming inventory. Only a small proportion of respondents to our survey have programs to preserve or acquire land or coordinate with adjacent jurisdictions. The 2012 ACGA and 2016 NCAT studies underscore the demand for more land. The former study indicated a waiting list of urban farmers; the latter study found that urban farmers cultivate more than one site.

However, Bonham, Spilka, \& Rastorfer (2002) observed that the land acquisition process is lengthy; likewise, the real estate market can compel the conversion of urban agricultural sites into residential or nonresidential development. For example, one respondent to our survey noted that the designation of rural land outside of a city as growth areas targeted for residential development precludes that land being available for agriculture. An exploration of external factors such as political support, citizen collaboration, and the state of the local economy and real estate market could shed 
further light on the changes in urban agriculture. A final question relates to the distribution of survey respondents at state and urban levels. Could regional and local demographic factors explain urban agriculture trends? As we observe in each decennial census, various urban regions gain population, while others decline or remain stable. The demographic link to urban agriculture trends is apparent. Population growth generates demand for land for new housing, resulting in the loss of land available for urban agriculture. This raises a question over whether population growth can significantly affect areas to the extent that less land is available for urban agriculture. We feel this warrants further study.

\section{Limitations of the Study}

This study only includes projects that the responding city planners were aware of. It is difficult to keep track of every incidence of urban agriculture in a local area, as it can be done on an ad hoc basis and is not always conspicuous. Our study only considered those projects that were subject to approval by administrative zoning permit or public hearing approval, part of the city's existing land use inventory. Planners may also not be aware of projects approved by other entities in the local jurisdictions, such as school districts. However, some planners were able to note school district and other types of projects as well. The responsibility of planners to periodically monitor land development in updating plans and zoning enforcement should also provide a reasonable assessment.

The survey identified the presence of certain policies and regulations, but it did not measure the quality or content of these programs. We focused mainly on urban agriculture growth and decline and the type of policy, regulatory, and program approaches in use. However, we were able to quantify changes in urban farming acreage and number of projects, though to a limited extent.

In analyzing trends, this study assesses reported change in urban agriculture between two points in time: 2000 and 2010. We thought it would be more feasible and less time-consuming for a respondent to provide a summary of net growth or decline during this period. The sample size of cities reporting a decline in urban agricul- ture is too low for rigorous regression analysis.

Another limitation may include selection bias.

The focus on cities in the South signifies a regional bias. However, the findings shed light on the development of urban agriculture practices in this region and address the limited geographic focus in community garden research noted by Guitart et al. (2012). Further, four of the cities that responded to the ACGA survey in 1998 responded to our survey.

Many external factors beyond local government programs affect urban agriculture. These factors include local and regional food insecurity, the work of nonprofit and private urban agriculture advocates, external funding, economic conditions, local real estate markets, and community resistance. These could serve as topics for further study.

\section{Conclusions}

We gained some important insight by examining similarities and differences in urban agriculture trends and practices in the South compared with those reported in national surveys. As in the case of the cited national surveys, we were encouraged to find urban agriculture growing in terms of acreage and projects in our sample of cities. However, when we examined the median number of projects and project acreage, this growth was modest.

Reports of obstacles from our sample of Southern U.S. cities were also similar to those reported in national surveys. These barriers included land conversion, economic sustainability of the site, and lack of funding. Economic sustainability implies a need for training to support business and agricultural expertise. Our findings also point to lack of funding. Most cities surveyed in the ACGA (2012) and NCAT (2016) studies noted a demand for urban agricultural land vis-à-vis inadequate funding. Further studies should also consider complexities in land acquisition, including Bonham's observation that the land acquisition process is lengthy (Bonham et al., 2002).

This study also charted new directions in research. First, in comparison to national surveys, we viewed urban agriculture as a comprehensive whole to include community supported and entrepreneurial agriculture. Indeed, our findings show that these forms of urban agriculture play an 
important role in local food production; together, they made up $19 \%$ of urban agriculture practices reported by our survey cities. Rather than survey community gardens, CSAs, and entrepreneurial agriculture in isolation, we encourage subsequent studies to take a broader perspective.

Second, both the cities reporting growth in urban agriculture and those experiencing decline used the same regulatory and policy tools. This calls for a further study regarding the quality and effectiveness of these tools to determine if they inadvertently create barriers.

Third, in comparison to other research, we surveyed Southern cities for interjurisdictional coordination. Among cities reporting urban agriculture growth, only $12 \%$ coordinated with adjacent jurisdictions. Given the precarious nature of farming on leaseholds, interjurisdictional coordination is important in extending the land inventory and providing further options on the urban fringe. In addition, most urban agriculture produce is perishable, so locations in peri-urban areas adjacent to the city are critical. It also reduces the length of vehicular trips to urban markets.

There is still a long way to go. What we learned also raised some issues for further exploration. What are the impacts of land use policies, regulations, and programs on securing reliable and diverse local food production? To what extent can local food organizations better educate and train urban farmers to be successful? What external factors are in direct conflict with planning for urban agricultural success, including population growth and the local real estate market? Finally, and most importantly, in holding barriers to urban agriculture in perspective and gaining a more detailed understanding of the problem, are decision-makers also solution-oriented? Advocates who face and overcome these obstacles provide us with a road map to our own success and understanding. As Robert Collier (1947/2009) noted, "In every adversity, there lies the seed of an equivalent advantage" (p. xv). We leave it to subsequent research to examine these issues.

\section{References}

American Community Garden Association. (1998). National Community Gardening Survey: 1996. College Park, Georgia: American Community Garden Association.

Bleasedale, T., Crouch, C., \& Harlan S. (2011). Community gardening in disadvantaged neighborhoods in Phoenix, Arizona: Aligning programs and perceptions. Journal of Agriculture, Food Systems, and Community Development, 1(3), 99113. https://doi.org/10.5304/jafscd.2011.013.007

Bonham, B., Spilka, G., \& Rastorfer, D. (2002). Old cities, green cities. Communities transform unmanaged land (PAS Report 506/507). Chicago: American Planning Association.Campbell, M. (2014). Building a common table: The role of planning in community food systems. Journal of Planning Education and Research, 23(4), 341-355. https://doi.org/10.1177/0739456X04264916

Castillo, S., Winkle, C., Krauss, S., Turkewitz, A., Silva, C., \& Heinemann, E. (2013). Regulatory and other barriers to urban and peri-urban agriculture: A case study of urban planners and urban farmers from the greater Chicago metropolitan area. Journal of Agriculture, Food System and Community Development, 3(3), 155-166. https://doi.org/10.5304/jafscd.2013.033.001

Coleman-Jenson, A., Rabbitt, M., Gregory, C., \& Singh, A. (2018). Household food security in the United States in 2017 (Economic Research Report No. 256). Retrieved from https://www.ers.usda.gov/webdocs/publications/90023/err-256.pdf.v $=0$

Collier, R. (2009). Riches within your reach. New York: Jeremy P. Tarcher/Penguin. (Original work published in 1947.)

Covert, M., \& Morales, A. (2014). Formalizing city farms: Conflict and conciliation. In V. Mukherji \& A. LoukaitouSideris (Eds.), The informal American city. Beyond taco trucks and day labor (pp. 193-208). Cambridge, MA: MIT Press.

Donofrio, G. (2014). Attacking distribution: Obsolescence and efficiency of food markets in the age of urban renewal. Journal of Planning History, 13(2), 136-159. https:///doi.org/10.1177/1538513213507540

Feenstra, G., McGrew, S., \& Campbell, D. (1999). Entrepreneurial community gardens: Growing food, skills, jobs and communities (Report No. 21587). Berkeley: University of California, Division of Agriculture and Natural Resources. https://anrcatalog.ucanr.edu/pdf/21587e.pdf 
Graham, H., Beall, D. L., Lussier, M., McLaughlin, P., \& Zidenberg-Cherr, S. (2005). Use of school gardens in academic instruction. Journal of Nutrition Education and Behavior, 17(3), 147-151. https://doi.org/10.1016/S1499-4046(06)60269-8

Guitart, D., Pickering, C., \& Byrne, J. (2012). Past results and future directions in urban community gardens research. Urban Forestry \& Urban Greening, 11(4), 364-373. https://doi.org/10.1016/j.ufug.2012.06.007

Heimlich, R.(2001). Metropolitan agriculture. Farming in the city's shadow. Journal of the American Planning Association, 55(4), 457-466. https://doi.org/10.1080/01944368908975434

Hodgson, K., Campbell, M., \& Bailkey, M. (2011). Urban agriculture: Growing bealthy, sustainable communities (Planning Advisory Service Report No. 563). Chicago: American Planning Association. Retrieved from https://www.planning.org/research/urbanagriculture/

Kaufman, J., \& Bailkey, B. (2000). Farming inside cities: Entrepreneurial urban agriculture in the United States (Working Paper WP00JK1). Cambridge, Massachusetts: Lincoln Institute of Land Policy.

Krones, S., \& Edelson, S. (2011). Building gardens, rebuilding a city: Baltimore's community greening resource network. Journal of Agriculture, Food Systems and Community Development, 1(3), 133-149. https://doi.org/10.5304/jafcsd.2011.013.005

Lawson, L., \& Drake, L. (2012). Community garden organization survey: 2011-2012. American Community Garden Association \& Rutgers School of Environmental and Biological Sciences. Retrieved from http://agriurban.rutgers.edu/Documents/Lawson $\% 20$ and $\% 20$ Drake $\% 20$ community $\% 20$ garden $\% 20$ survey $\% 20$ rep ort.pdf

Linn, K. (1999). Reclaiming the sacred commons. New Village Journal, 1, 1-8. Retrieved from https://www.newvillage.net/

Lovell, S. (2010). Multifunctional urban agriculture for sustainable land use planning in the United States. Sustainability, 2(8), 2499-2522. https://doi.org/10.3390/su2082499

Masson-Minock, M., \& Stockman, D. (2010). Creating a legal framework for urban agriculture: Lessons learned from Flint, Michigan. Journal of Agriculture, Food Systems, and Community Development, 1(2), 91-104. https://doi.org/10.5304/jafscd.2010.012.007

Mukherji, N. (2009). The promise and the pitfalls of municipal policy for urban agriculture (Unpublished master's thesis). University of Wisconsin-Madison, Wisconsin.

Mukherji, N., \& Morales, A. (2010). Zoning for urban agriculture. Zoning Practice, 3(March), 2-7. https://www.planning.org/zoningpractice/

Oberholtzer, L., Clancy, K., \& Esseks, J. (2010). The future of farming on the urban edge: Insights from fifteen U.S. counties about farmland protection and farm viability. Journal of Agriculture, Food Systems, and Community Development, 1(2), 59-76. https://doi.org/10.5304/jafscd.2010.012.003

Oberholtzer, L., Dimitri, C., \& Pressman, A. (2016). Urban agriculture in the United States: Baseline findings of a nationwide survey. National Center for Appropriate Technology. Retrieved from https://attra.ncat.org/attra-pub/summaries/summary.php?pub $=558$

Parmer, S., Salisbury-Glennon, J., Shannon, D., \& Struempler, B. (2009). School gardens: An experiential approach for a nutrition education program to increase fruit and vegetable knowledge, preference and consumption among secondgrade students. Journal of Nutrition Education and Behavior, 41(3), 212-217. https://doi.org/10.1016/i.jneb.2008.06.002

Pothukuchi, K., \& Kaufman, J. (1999). Placing the food system on the urban agenda: The role of municipal institutions in food systems planning. Agriculture and Human Values, 16(2), 213-224. https://doi.org/10.1023/A:1007558805953

Raja, S., Born, B., \& Kozlowski-Russell, J. (2008). A planner's guide to community and regional food planning (Planning Advisory Service Report No. 554). Chicago: American Planning Association. Retrieved from https://www.planning.org/publications/report/9026878/

Ratcliffe, M. M., Merrigan, K. A., Rogers, B. L., \& Goldberg, J. P. (2011). The effects of school garden experiences on middle school-aged students' knowledge, attitudes and behaviors associated with vegetable consumption. Health Promotion Practice, 12(1), 36-43. https://doi.org/10.1177/1524839909349182

Schmelzkopf, K. (1995). Urban community gardens as contested open space. Geographical Review, 85(3), 364-381. https://doi.org/10.2307/215279 
Schukoske, J. E. (2000). Community development through gardening: State and local policies transforming urban open space. N.Y.U. Journal of Legislation and Public Policy, 3(2), 351-392. https://doi.org/10.2139/ssrn.1426079

Sharp, J., Jackson-Smith, D., \& Smith, L. (2011). Agricultural economic development at the rural-urban interface: Community organization, policy, and agricultural change. Journal of Agriculture, Food Systems, and Community Development, 1(4), 189-204. https://doi.org/10.5304/jafscd.2011.014.002

Smith, C. M., \& Kurtz, H. E. (2003). Community gardens and politics of scale in New York City. Geographical Review, 93(2), 193-212. https://doi.org/10.1111/j.1931-0846.2003.tb00029.x

Thibert, J. (2012). Making local planning work for urban agriculture in the North American context: A view from the ground. Journal of Planning Education and Research, 32(3), 349-357. https://doi.org/10.1177/0739456X11431692

Tixier, P., \& Bonn, H. (2006). Urban horticulture. In R. Veenhuizeen (Ed.), Cities farming for the future: Urban agriculture for green and productive cities (pp. 315-347). Silang, Cavite, Philippines: International Institute of Rural Reconstruction \& FTC Urban Agriculture.

U.S. Census Bureau. (2011a). Table 5: Estimates of population change for Metropolitan Statistical Areas and rankings. July 1, 2010-July 1, 2011.

U.S. Census Bureau. (2011b). Table 1: Population Change for the United States, Regions, States, and Puerto Rico: 2000 to 2010. U.S. Census Briefs. Retrieved from https://www.census.gov/prod/cen2010/briefs/c2010br-01.pdf

U.S. Census Bureau. (2018). Historical Poverty Tables: People and Families: 1959-2017. Table 9: Poverty of People by Region, 1959-2017. Retrieved from https://www.census.gov/data/tables/time-series/demo/income-poverty/historical-poverty-people.html

U.S. Census Bureau, American Community Survey Office. (2018). Census regions and divisions in the United States. Retrieved from https://www2.census.gov/programs-surveys/sahie/reference-maps/2017/us-regdiv.pdf

U.S. Department of Agriculture (2017a). Food insecurity in the United States. Retrieved from https://www.ers.usda.gov/topics/food-nutrition-assistance/food-security-in-the-us/key-statistics-graphics.aspx

U.S. Department of Agriculture (2017b). Table 2: Households by food security status and selected household characteristics, 2017. Retrieved from https://www.ers.usda.gov/webdocs/publications/90023/err-256.pdf

Veenhuizen, R. (Ed.). (2006). Cities farming for the future: Urban agriculture for green and productive cities. Silang, Cavite, Philippines: International Institute of Rural Reconstruction and FTC Urban Agriculture. 


\section{Appendix 1. Urban Agriculture Survey - Selected Questions}

1. Approximately how many acres of land in your city are dedicated to urban agriculture?

No. of Acres:

2. Which of the following designate areas for urban agriculture use in your city?
A) Comprehensive Plan
Yes
No
B) Neighborhood Plan
Yes
No
C) Land Use Policy Map
Yes
No
D) Open Space Plan
Yes
No
E) Other (Please Specify):

3. How long has urban agriculture been implemented within your city?

No. of Years:

4. Out of the series below, please circle the method which your city uses to regulate urban agriculture (circle all that apply):
A) Urban Agriculture Ordinance.
B) Zoning Ordinance.
C) Parks and Recreation Regulations.
D) Other (Please Specify):
E) No regulation.

5. If known, list below the proportion of urban agricultural land that is under public or private ownership (definition of public ownership includes government and other nonprofit organizations):

Public: _ _ $\%$

Private:

6. Provide the number of types of urban agriculture projects in your city.

_ Neighborhood Gardens _ _ Senior Center/Senior Citizen Housing Gardens 
_ Public Housing Gardens _ _ Community Supported Agriculture

_ School Gardens _ _ Job Training

Youth Enterprises

_ Commercial Farm Sites _ _ Mental Health Centers (shelters, group homes)

_ University Project _ _ Agricultural Research Demonstration Project

_ Other types (Please specify):

7. Does your city have policies or programs which preserve urban agriculture use on parcels under private ownership?

No:

If you answered "Yes" please provide a description of the policies or programs below (you may also use the last page of this survey or attach information to elaborate):

8. Does your city have policies or programs which purchase parcels for public urban agriculture use?

Yes:

No:

9. Has urban agriculture use grown or declined in your city over the past 10 years?
A) Grown
B) Declined

If known, how much has urban agriculture use grown or declined in terms of acres of land or number of projects?

Acres: Number of Projects:

10. If urban agriculture has declined in your city circle the following reasons that apply:
A) Lack of funding.
B) Lack of available sites.
C) Conversion of private land to private residential or nonresidential use.
D) Conversion of public land for community development purposes (e.g., neighborhood redevelopment, affordable housing).
E) Conversion of land to park or recreation facilities.
F) Gentrification
G) Gardeners' lack of interest. 


\begin{abstract}
H) Vandalism or theft.
\end{abstract}
I) Failure of site to sustain itself economically.

J) Changing city priorities.

K) Other (Please specify):

11. Does your city coordinate with adjacent jurisdictions in developing urban agriculture areas?
Yes:
No:

Thank you for your response. Please complete the contact information below:

City \& State:

Name:

Title:

Organization:

Phone:

E-mail: 


\section{Appendix 2. Responding Cities}

$\begin{array}{ll}\text { Asheville, NC } & \text { Lexington, KY } \\ \text { Augusta, GA } & \text { Lubbock, TX } \\ \text { Austin, TX } & \text { Lynchburg, VA } \\ \text { Baytown, TX } & \text { Marco Island, FL } \\ \text { Bossier City, LA } & \text { Maudlin, SC } \\ \text { Bristol, TN } & \text { Melbourne, FL } \\ \text { Cape Coral, FL } & \text { Montgomery, AL } \\ \text { Chapel Hill, NC } & \text { Myrtle Beach, SC } \\ \text { Clarksburg, WV } & \text { Norfolk, VA } \\ \text { Clarksville, TN } & \text { North Charleston, SC } \\ \text { College Station, TX } & \text { North Little Rock, AR } \\ \text { Columbia, SC } & \text { Parkersburg, WV } \\ \text { Columbus, GA } & \text { Pensacola, FL } \\ \text { Conway, AR } & \text { Pompano Beach, FL } \\ \text { Conway, SC } & \text { Port Arthur, TX } \\ \text { Corpus Christi, TX } & \text { San Antonio, TX } \\ \text { Deltona, FL } & \text { Sandy Springs, GA } \\ \text { Durham, NC } & \text { Sanford, FL } \\ \text { Fairmont, WV } & \text { Sarasota, FL } \\ \text { Fort Myers, FL } & \text { Summerville, SC } \\ \text { Fort Worth, TX } & \text { Temple, TX } \\ \text { Gaithersburg, MD } & \text { Tulsa, OK } \\ \text { Houma, LA } & \text { Washington, DC } \\ \text { Huntsville, AL } & \text { Wheeling, WV } \\ \text { Jackson, MS } & \text { Wilmington, DE } \\ \text { Jacksonville, FL } & \text { Winston-Salem, NC } \\ \text { Killeen, TX } & \text { Winter Haven, FL } \\ \text { Kingspor, TN } & \end{array}$

